\title{
FREE SPEECH AND EXTRINSICALLY UNJUST LAWS IN THE THEORY OF JOHN FINNIS
}

\author{
SVOBODA PROJEVU A EXTERNĚ NESPRAVEDLIVÉ \\ ZÁKONY V TEORII JOHNA FINNISE
}

\author{
Petr Osina ${ }^{1}$ \\ https://doi.org/10.33542/SIC2021-2-05
}

\begin{abstract}
The article deals with the concept of free speach in New Natural Law theory in the conception of its main representative John Finnis. At the beginning it concentrates on the description of free speach in the context of the Finnis's theory of extrinsically unjust laws. The article continues with the analysis of criminal case from the beginning of the USA and the application of Finnis's theory on this problem. The weak aspects of the concept of common good in Finnis's theory are analyzed at the end of the article.
\end{abstract}

\begin{abstract}
ABSTRAKT
Článek se věnuje analýze konceptu svobody projevu v učení Nové teorie přrirozeného práva v pojetí jejiho hlavního představitele Johna Finnise. Na začátku se zabývá vymezením svobody projevu ve vztahu k Finnisově pojetí externě nespravedlivých zákonů. Na to navazuje analýza trestni kauzy z počátkủ existence USA a aplikace Finnisova pojetí na tento prípad. V závěru je pak pojednáno o slabých místech Finnisovy koncepce obecného dobra.
\end{abstract}

\section{INTRODUCTION}

Many trials in early America were concerned with sedition laws and free expression. Free expression was given a back seat to a government's right to protect itself in the face of seditious speech or acts. These anti-sedition statutes called for the substantial punishment of anyone who expressed political speech that might have caused political instability.

We will examine an early American unjust sedition statute that may highlight general theoretical problems in Finnis's theory of extrinsically unjust laws and our duty to obey them. For our purposes, anti-sedition statutes are extrinsically unjust laws because they are violations of the common good rather than violations of exceptionless norms or direct attacks on basic goods, since free speech is not named as a basic good in Finnis's theory. ${ }^{2}$

\section{POLITICAL FREE SPEECH AND EXTRINSICALLY UNJUST LAWS}

One might argue that, in some instances, these anti-sedition laws may be intrinsically unjust laws because they attack the basic good of knowledge, and that would be one way to eliminate many problems because we would have no duty to obey them under Finnis's theory. In other words, if one re-characterizes any law from an extrinsically unjust law to an intrinsically unjust law, then one avoids the challenges associated with an extrinsically unjust law - the generic and presumptive duty to obey and the complicated common good analysis. ${ }^{3}$

The first example is designed to illustrate this "re-characterization" possibility, as well as to

1 JUDr., Ph.D., Univerzita Palackého v Olomouci, Právnická fakulta, Česká republika

Palacky University Olomouc, Faculty of Law, Czech republic

2 FINNIS, J. Natural Law and Natural Rights. Second Edition. Oxford: Oxford University Press, 2011, p. 85.

3 FINNIS, J. Law's Authority and Social Theory's Predicament, in: Philosophy of Law: Collected Essays, Volume IV, Oxford University Press, 2011, p. 48. 
show that it is not clear how Finnis protects us against abuses of the generic and presumptive duty to obey without using a basic good analysis. The second example is designed to show that Finnis's theory of extrinsically unjust laws and the common good analysis it entails are of little help to those who are confronted with whether to obey anti-sedition statutes or perhaps any extrinsically unjust law because the common good analysis leaves the citizen with too many variables to apply to any given case.

In order to understand these theoretical limitations of Finnis's theory of extrinsically unjust laws both in general and as they are manifest in anti-sedition statutes in particular, an important distinction needs to be made in free speech law. The distinction is between prior restraint and subsequent punishment.

Prior restraint refers to the way that an authority suppresses information before it is published or spoken, that is, the authority attempts through a restrictive never to allow such speech to be spoken. Prior restraint is regarded as a very intrusive invasion of free expression. ${ }^{4}$ Subsequent punishment refers to a process (usually a trial in a court) whereby speech is evaluated by judge or jury after it is published or spoken. Because it allows speech to be spoken or written, this is viewed as a less intrusive invasion on free speech. ${ }^{5}$

It is possible to use either of these kinds of regulation techniques in law to highlight certain problems in Finnis's theory because they both restrict political free speech. We choose to use prior restraint laws to highlight how the generic and presumptive duty to obey the law may be abused because prior restraint laws are more obvious direct attacks on free speech. We use subsequent punishment laws to highlight certain limitations in Finnis's common good analysis because subsequent punishment laws are less an attack on political speech. The use of prior restraint and subsequent punishment laws to highlight these points is arbitrary, but the application works well to show both particular limitations of Finnis's theory in free speech cases as well as some general limitations in Finnis's overall theory of extrinsically unjust laws and our duty to obey them.

Prior restraint laws are a more serious suppression of free speech through oppressive regulation because their intent is to never allow speech to be spoken or published. Prior restraint laws illustrate the importance of making free speech a basic good because without free speech as basic good, we may be asked to honor the generic and presumptive duty to obey the law when we should not. The first case is designed to show how the generic and presumptive duty to obey may be abused in free speech prior restraint laws.

It is important to point out that this tendency of the abuse of the generic and presumptive duty to obey the law may be systemic to Finnis's theory of our duty to obey an extrinsically unjust law. The prior restraint cases have the virtue of bringing out this potential negative in Finnis's theory. We may hypothesize that when faced with any other kind of extrinsically unjust law that violates our cherished values, we need to be on the lookout for an oppressive application of the generic and presumptive duty to obey the law.

Subsequent punishment laws attack free speech less directly by allowing it to be spoken. These laws provide to us a way to examine Finnis's theory of extrinsically unjust laws in a way other than by suggesting that we must make free speech a basic good. Subsequent punishment statutes are subject more to the "double moral assessment movement" because they do not involve a direct attack on a cherished good even though it may not be basic.

Finnis's "double moral assessment movement" and the common good analysis upon which it relies do not provide enough force for us to say that political free speech is entitled to be protected. The second example below relates to a subsequent punishment law and the example attempts to show that if we decide not to re-characterize an extrinsically unjust law by naming free speech a basic good, then our moral obligation to obey the law, under a common good analysis, may be

\footnotetext{
4 OAKES, J. The Doctrine of Prior Restraint Since the Pentagon Papers. University of Michigan Journal of Law Reform, Vol. 15, 1982, p. 498.

5 EMERSON, T. The Doctrine of Prior Restraint. Law and Contemporary Problems, Vol. 20, 1955, p. 648.
} 
impossible to determine because of the necessity to consider so many variables.

\section{GENERIC AND PRESUMPTIVE DUTY TO OBEY THE LAW}

Assume that country A is contemplating going to war against country B because country B has weapons of mass destruction, and country A is contemplating killing only combatants (thereby respecting the exceptionless norm doctrine against killing the innocent). Country A has a statute $\mathrm{L}$ on the books that prohibits anyone, journalist or otherwise, from printing information about the government that would be likely to lead to an insurrection.

Assume also that a journalist from country A has obtained secret information questioning the existence of weapons of mass destruction in country B. Assume further that the secret police in country A knows that the journalist is going to publish the secret information. Upon orders from their commander to enforce Statute L, the secret police seizes the journalist before he publishes the information because they believe that the information he has, is credible, and they know full well that, if it is published, it might create a public outcry and possibly lead to an insurrection. Insurrection may result because the government is misleading the public about the existence of the weapons of mass destruction.

Under Finnis's view, a plausible argument can be made that the journalist has a moral obligation to obey oppressive statute L. ${ }^{6}$ The journalist has a moral obligation to obey statute $\mathrm{L}$ and not print the material because his generic and presumptive duty to obey the law is not defeasible. In his decision not to publish the material, the journalist would experience prior restraint on his free speech rights.

The restraint on his free speech rights would prohibit a whole nation from knowing that the country is contemplating a possible course of action that may irrationally neglect or not fully appreciate the common good. A moral duty to obey the oppressive anti-sedition statute is possible under Finnis's theory because his theory has little way of making the right of free expression equivalent to other kinds of values like the common good's interest in political stability. On account of this deficiency, the journalist may think wrongly that he has a generic and presumptive duty to obey statute $\mathrm{L}$ that directs him not to publish the inflammatory information.

What we are attempting to show with statute L is that Finnis's theory can be accused of allowing a doctrine of excessive prior restraint because it is short on the importance of political free speech. The right to express one's views should not be curtailed because of political instability, unless there is a clear and present danger to a society. The point that Finnis's theory, in the absence of allowing free speech to be a basic good, may allow for the suppression of free speech.

The identification of free speech as basic good would allow laws suppressing free speech to be treated as intrinsically rather than extrinsically unjust laws. The journalist, under these circumstances, would have a moral obligation to publish the information, otherwise he would directly attack the basic good of free speech. The problem is that Finnis's notion of common good can be used to suppress much political speech which should be expressed. It may seem that this argument is contorted in that one may question whether free speech requires that everyone must say what they know is true.

The answer to this is that it is not a question of whether we must say what we know is true. Rather it is that we must have the right to say what it is true or false in the political arena. The notion of free speech has less to do with the advancement of knowledge and more to do with the idea that we simply should be allowed to speak about our political opinions without fear of reprisal.

The nature of a view has little to do with the right to express them. One might say that Finnis's basic good of knowledge covers the basic good of political free speech in that it treats free speech as instrumental for knowledge. This would be acceptable if one thought that the primary function of free speech is attain the truth. But there are other reasons for making political free speech a basic good other than to advance the truth.

6 FINNIS, J. Natural Law and Natural Rights. Second Edition. Oxford: Oxford University Press, 2011, p. 318. 
First, it is a good in and of itself. The idea is reflected in the statement "I disapprove of what you say but I will defend to the death your right to say it". ${ }^{7}$ One should not be stifled. Second, the mind must be free from many constraints if human fulfillment is to be achieved, one such restraint is the curtailment of freedom of expression which damages the openness that so many democracies depend on. Third, some lawyers talk about the necessity of political free speech as a safety valve to allow people to let off steam to prevent revolutions in a society. Political free speech allows for a more healthy exchange of ideas in a democracy in that it allows for different ideas to blend together more effectively. ${ }^{8}$ Political free speech also prevents against the manipulation of public opinion by allowing all opinions to be expressed. In this way, it can act as a protection against different forms of tyranny. The law over the last one hundred years has moved away from the use of prior restraint in an attempt to allow persons other than those in political power to judge whether the speech at issue is pernicious and punishable. The idea to allow expression is that those in political power have historically dishonored and even slaughtered subjects who have tried to speak against their governments. Finnis's theory seems to neglect the drift away from the use of prior restraint in free speech law. Consequently the theory runs the danger of allowing too little political freedom in the individual and thereby subjects him to an oppressive duty to obey where there should be none.

\section{FREE SPEECH AS A BASIC GOOD}

What needs to be considered is the problem of protecting against rulers like Mao in China, who allowed free speech to occur, but only in as much as it promoted his own agenda for the common good. As he says "Our literary art workers must accomplish this task and shift their stand to the side of the proletariat. In only this way can we have a literature and art that are truly for the workers, peasants, and soldiers, a truly proletariat art and literature. ${ }^{\text {" } 9}$

The inclusion of free speech as a basic good stops the leader from saying one thing and doing another. People should be free to point out all hypocrisy in their government whenever they choose. John Stuart Mill believed that the suppression of free speech creates at least two problems - we lose the truth if such suppressed speech were true and even if the speech is false, it still might help us to sharpen our position by explaining to the other side what is wrong about the speech that attacks our own. ${ }^{10}$

Finnis may not have to look very far from his own work to see that the idea is already implicit in his own writings. One could argue that Finnis's theory does not have the idea implicit in his work: "Political liberty, for example, is a great good, but it is not itself basic, for it by itself does not fulfill persons but only enables them to pursue various forms of fulfillment." 11 This position does not seem intuitively obvious because without political freedom, very few basic goods could ever be recognized, let alone achieved. In addition, the idea is not that full political liberty should be a basic good, but that the right to political free speech should be a basic good.

Finnis discusses the idea of ethical discourse in Plato's Gorgias. He says that Plato recognized the importance of the difference between speech-making and discourse, the former aimed at persuasion and the latter aimed at truth. Finnis states Plato's conditions for discourse in the Gorgias in the following way: "The conditions? Knowledge, good will, and frankness: (i) a sound, wide ranging education (ii) good will towards the other parties to the discourse/discussion, and (iii) willingness to speak frankly (even when that involves admitting one's mistakes, self contradictions, and self refutation) and not to feign agreement." Finnis endorses Plato's view of discourse. ${ }^{12}$

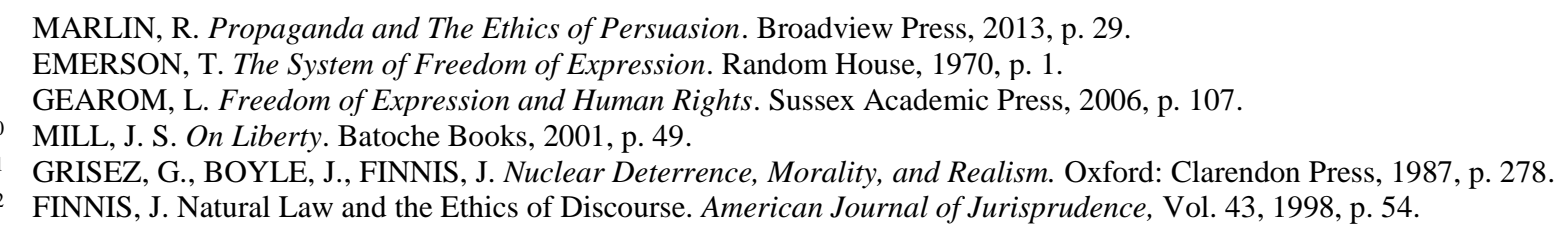


The value of the third condition, frankness in discourse, is instructive on the issue of free speech because without it there cannot be any true discourse. Individuals should not be afraid to speak their minds about important political events or political topics out of the fear of being punished by an authority when they are seeking to discover the truth. The inclusion of free speech as basic good would help to encourage openness in discourse about political matters and help diminish the tendency of a government to compel its citizens to a blind or coerced obedience. Frankness in discussion would also encourage governments to be more candid with their citizens about the rationale behind government actions and laws.

Why should we make free speech a basic good? Other than to counterbalance the generic and presumptive duty to obey the law, to encourage frankness in discussion, and to encourage the free flow of information in a society, another good reason is that free speech has already been recognized as a basic good by many societies. One might think that these recognitions are instrumental in some way and not substantive. But when we notice language such as the right to free speech is "the right to hold opinions without interference", ${ }^{13}$ we sense that free speech is more connected with the tolerance of peoples views than on the advancement of knowledge.

Consider the following documents - The First Amendment of the United States Constitution, The European Convention on Human Rights, The American Declaration of Rights and Duties of Man, The United Nations Universal Declaration of Human Rights. These documents are designed to prevent political oppression as well as the suppression of religious and political ideas. The idea of free speech as a basic good would be consistent with what many authorities in free and open societies already believe about the value of free speech, that it is indispensable to good living or what Finnis calls integral human fulfillment. ${ }^{14}$

Further, there is no prohibition on adding free speech as a basic good to the other basic goods in Finnis's theory because he tells us that the list is open to the addition of other basic goods. There is no magic in the number seven, and others who have reflected on these matters have produced slightly different lists, usually longer. ${ }^{15}$ There is no need for the reader to accept the present list, just as it stands still less its nomenclature which simply gestures towards categories of human purpose that are each unified, and nevertheless multifaceted. ${ }^{16}$

There is no exclusion here in promoting other basic goods. In fact, Finnis seems to be saying that he would welcome the addition of more basic goods if they were consistent with his theory. In fact, he and his colleagues have already added an eighth to the earlier list of seven, namely, marriage. We suggest that political free speech should be made a part of the list.

\section{THE COMMON GOOD ANALYSIS}

Finnis's theory of extrinsically unjust laws allows compelling arguments to be made for and against a duty to obey when there is no direct attack against a basic good. This means that Finnis's theory may not be used to have us disobey many statutes that are counterintuitive to us, like the statute we discuss in this section. The major problem is that Finnis's common good analysis is so complicated that we are arguably paralyzed in our ability to understand our moral obligation beyond our duty to obey existing law: the generic presumptive duty to obey the law. When we are faced with any extrinsically unjust law, we are usually going to have to obey it because the common good analysis cannot point us to a duty to obey or not to obey. Finnis's common good analysis puts us in kind of a stalemate position and under these circumstances the presumption to obey the law trumps.

It will serve us well if we remember a distinction in free speech law before we examine the selected case. The distinction helps us to clarify the nature of political free speech. The distinction

13 The International Covenant on Civil and Political Rights, Article 19.

14 FINNIS, J. What is the Common Good, and Why Does It Concern the Client's Lawyer? South Texas Law Review, Vol. 41, 1999, p. 44.

15 CROWE, J. Natural Law and the Nature of Law. Cambridge: Cambridge University Press, 2019, p. 35.

16 FINNIS, J. Natural Law and Natural Rights. Second Edition. Oxford: Oxford University Press, 2011, p. 92. 
is between what is and what is not political free speech.

Political free speech is not commercial speech, which involves the right to say that glass is perhaps a diamond, but not that a piece of glass is a diamond, to bring about a sale. Political free speech is not slanderous speech where the law requires that someone tell the truth; for instance, a person cannot say in a legal allegation against a restaurant that the food he or she just ate at a restaurant made him or her sick when, in fact, the food did not. Political free speech is not speech that creates a danger in a private setting, like someone shouting "Fire!" in a crowded theater where there is no fire.

Political speech is speech that is directed at a legitimate government or its officials. But political speech is not action, such as causing physical damage to government property as an expression of a political ideal. We now turn to a consideration of our selected subsequent punishment case to show the major limitations of Finnis's theory of extrinsically unjust laws and our moral duty to obey them.

An early American legal case involved a Congressman in the United States who made some derogatory remarks about the President of the United States. The Congressman was then prosecuted successfully by the United States Government under the Act for The Punishment For Certain Crimes of Seditious Libel from 1798. This act provided that, if any person shall write, print, utter or publish or shall cause or procure to be written, of printed, uttered, or published, any false, scandalous and malicious writing or writings against the government of the United States... such person shall be punished by a fine not exceeding two thousand dollars, and by imprisonment not exceeding two years. ${ }^{17}$

One could argue that the intent of this statute was not only to punish seditious speech after it was spoken, but also to instill the fear of publication in an author and thereby establish a kind of prior restraint in the government's subjects. Our argument focuses on the problem of subsequent punishment in this case in that the statute is so broad that it will allow just about everything said that is negative about the President of the United States to be prosecuted including calling him a "liar". The point is to suggest that Finnis's theory of extrinsically unjust laws could potentially be used to uphold a duty to obey statutes similar to the 1798 Sedition Act or even to justify the statute itself.

The punishment case is the case of United States v. Matthew Lyon. Born in 1749 in Ireland, Lyon was apprenticed to a printer and then sailed for America in 1764 as an indentured servant. During the American Revolutionary War, Lyon served as a colonel. After the signing of the Declaration of Independence, he joined the Continental Army and served as a second lieutenant under George Washington. When Vermont declared its independence from New York and became a state in 1776, Lyon became a member of revolutionary Vermont's government. After the war, he settled down with his family and became a prosperous businessman. ${ }^{18}$

Lyon won a seat in the U.S. House of Representatives in 1796. He aimed most of his attacks at President John Adams and wrote a series of public letters that attacked Adams for seeking power, thirsting for pomp and adulation, demonstrating avarice, and dismissing meritorious men from office because of their independence of thought. Vermont Federalists charged Lyon with being criminally guilty of acting in opposition to the President. In October 1798 Lyon was indicted under the Sedition Act, the first test of this law. ${ }^{19}$

Lyon acted as his own attorney during the trial. He cross-examined witnesses and pleaded his own defense. Lyon argued the general Republican position that the seditious libel laws were the exclusive province of state legislation. He challenged the constitutionality of the Sedition Act on the grounds that it violated the First Amendment's protection of freedom of speech. The jury

\footnotetext{
17 The Sedition Act of 1798 - http://www.let.rug.nl/usa/documents/1786-1800/the-sedition-act-of-1798.php.

18 RACHLIN, R. D. The Sedition Act of 1798 and the East-West Political Divide in Vermont. The Journal of the Vermont Historical Society, Vol. 78, No. 2, 2010, p. 135.

19 Ibid., p. 138.
} 
deliberated for an hour before finding Lyon guilty. The judge sentenced him to four months imprisonment and to further confinement until he had paid the costs of the prosecution and a fine of 1.000 dollars.

Instead of silencing Lyon, prison made a martyr of him. The people of western Vermont responded by giving Lyon a landslide victory in his reelection campaign. When Lyon left jail, he returned to Congress, where, helping to resolve the presidential election of 1800 , he cast the tiebreaking vote for Thomas Jefferson over Aaron Burr. Lyon's imprisonment had made civil liberties one of the major campaign issues of the election. His jailing illustrated the extent to which the Federalists were stifling the right to dissent. Jefferson's victory gave him some vindication. Lyon moved to Kentucky and continued to serve in the House until 1811 . He died in $1822 .{ }^{20}$

We must ask whether we can use Finnis's theory to justify that Congressman Lyons had a moral duty to not publish the documents and thereby abide by the 1798 Act because of the generic and presumptive duty to obey the law. We may conclude that Finnis's theory could be used to justify a moral duty to obey the archaic and oppressive legal statute. We can apply Finnis's theory of our duty to obey extrinsically unjust laws to the 1798 Act to reveal the limitations of Finnis's theory.

The Lyons case is useful for our purposes because we can use it to show the working of Finnis's theory of extrinsically unjust laws and our duty to obey them. The Lyons case shows how Finnis's theory is deficient in its protection of free speech and in its tendency to produce equally good arguments for and against obedience to extrinsically unjust laws based on a common good analysis.

One could argue equally well with Finnis's theory that Congressman Lyons had no moral duty to obey the 1798 Sedition Act and that Congressman Lyons did have a moral duty to obey this Act. We can view this as a strange result because the anti-sedition statute from today's standards is so radically oppressive of free speech. Let us look more closely at this tendency in Finnis's theory. We can do this by seeing how one could make equally plausible arguments for both sides of the issue. First, how would one argue that Lyons did not have a moral duty to support the 1798 Act based on Finnis's theory.

The process of evaluating the 1798 Sedition Act and our duty to obey it lies in the double moral assessment movement. The first movement is the determination that the statute is an extrinsically unjust law. One could argue that the statute forces us to suppress too much information and thereby attacks the common good and justice and that the intent and effect of the statute creates an atmosphere of suppression that is both distributively and commutatively unjust. ${ }^{21}$ How would we say that the statute violates the common good because it is deficient in justice?

Finnis tells us that there is no precise yardstick for determining distributive justice, but he does give to us five assessment components. The most fundamental of these components is need. ${ }^{22}$ Under this component of distributive justice, a strong argument can be made that a community needs to know what is happening with their government, especially when times are difficult for a nation. In an effort to get relevant information about a government, wide discovery should be granted to the citizenry.

The suppression of free speech does not recognize the need for free information that is critical for a nation's need to know. The suppression of free speech does not honor the idea that full access to citizenry opinion fulfills a nations' need to be better informed about its policies and political figures. A nation needs the free flow of information in order to thrive. The free flow of information should come from both the citizenry and the elected officials of the government from the different branches of government. A nation that only allows a few people to speak is distributively unjust when the need for the country to hear everyone speak is necessary to allow ideas to circulate.

\footnotetext{
20 RACHLIN, R. D. The Sedition Act of 1798 and the East-West Political Divide in Vermont. The Journal of the Vermont Historical Society, Vol. 78, No. 2, 2010, p. 140.

21 FINNIS, J. Natural Law and Natural Rights. Second Edition. Oxford: Oxford University Press, 2011, p. 166.

22 Ibid., p. 174.
} 
Another way to make this argument is to suggest that the 1798 Act is distributively unjust because it only attends to one set of needs in the community - the rulers' needs. Some laws are made by a ruler and only the ruler stands to gain by those laws. The example is a ruler who took land for himself under an executive act at the expense of the public who needed the same land for public housing. This kind of problem with authority was called self-dealing. A good argument can be made that the 1798 Act was enacted only for the benefit of the existing government so that it could insulate itself against criticisms in an effort to galvanize political power. Absolute authority in a ruler also violates the rule of law and distributive justice.

In addition to the 1798 Act's distributive unjustness, one could argue that the Act is also commutatively unjust. The whole point of this kind of justice is to bring about a culture in which the rights and duties among individual parties are respected. Any law that suppresses the free flow of information may negatively impact individuals because they may not be able to communicate among themselves about important matters that may affect their lives through the duties and promises they make to each other.

For instance, assume for a moment that during the time of the 1798 Sedition Act, it was rumored that the government was about to massively over regulate and tax businesses who make new contracts, and many businesses resented the potential of more regulation and taxes on their businesses. The rumors about the government create suspicions and make people fearful about what they are going to do with one another because they do not what the government is going to do with any of them next.

Also assume that some of the people in possession of the rumor are journalists and that they do not want to divulge the full details of the rumor, let alone criticize lawmakers about the new tax regulations, because the journalists are afraid of being prosecuted under the 1798 Sedition Act due to the explosive consequences of new taxes on people and businesses. The journalists think that they have a duty to obey the anti-sedition statute because they believe that even if there was a chance that the rumored information was wrong, they would be imprisoned.

If it turned out that the rumor were true and the journalists never published it out of their fear of prosecution, the commutative justice between business people would be affected in that those who were doing business with one another without knowledge of changes in the tax law might enter into damaging new contracts that they would not have entered into had they known about the new taxes and regulations.

The commutative justice between the parties would also be effected because once they found that information was withheld from them, it would create an atmosphere of distrust and fear. Under these conditions, people may be less willing to engage with one another because of the uncertainty created by the government's lack of directness in dealing with its subjects. The point is that the right to publish a rumor should not be interfered with by the government not only because freedom of expression advances knowledge, but also because a political culture is viewed less suspiciously if citizens believe everything is out in the open, and a citizenry that trusts its government is more apt to conduct business with each other. Many businesses would be better off, from a commutative justice standpoint, if they knew that oppressive taxes and regulations were about to be levied against their businesses as a consequence of them entering into new contracts.

In effect, one could argue that the 1798 Sedition Act is an extrinsically unjust law because it violates the common good requirements of distributive and commutative justice. It should be noted that the components of distributive and commutative justice are sufficiently vague to allow one to make a determination that the statute is not extrinsically unjust. Thus one could argue that the first phase of the "double moral assessment" could go either way in the determination that an extrinsically unjust laws exists. If one finds that a law is not unjust, then one would have a duty to obey the law. In our analysis of the two sidedness of Finnis's theory, we focus less on the actual determination that the 1798 Act is extrinsically unjust (the first phase of the double moral assessment), and more on the second phase of the double assessment movement (the question of 
whether we have a duty to obey an extrinsically unjust law).

We saw earlier that once it is established that an extrinsically unjust laws exists, it becomes necessary to do the defeasibility analysis because the mere existence of an extrinsically unjust law (unlike an intrinsically unjust law) is not enough to justify an act of non-compliance. Thus after we apply the first phase of the "double moral assessment movement", we must apply the second phase - the generic and presumptive duty to obey and its defeasibility. This entails an examination of whether the presumption to follow a law is itself unjust based on a common good analysis.

It is here, in the application of the defeasibilty analysis that we see that the duty to obey argument cannot be determined because it is not clear if the generic and presumptive duty to obey the law is outweighed by the common good analysis. We can see this problem by arguing for and against a duty to obey the 1798 Act.

First, did Lyons have a generic and presumptive duty to obey the 1798 Sedition Act? The 1798 Sedition Act is an extrinsically unjust law and the presumption to obey it is defeasible if certain conditions exist. Finnis does not say if all or only one factor needs to be present to determine defeasibility, but he does emphasize that the tendency to create instability in a society is a significant reason to obey an extrinsically unjust law. ${ }^{23}$

One could argue that the 1798 Sedition Act demands our compliance because it enhances communal coordination and collaboration by preventing the political and criminal chaos that may potentially result from an act of disobedience. Thus, a person might say that the risk of civil insurrection is too high if a person disobeys the Act. A person simply cannot disobey a law if it means that the entire society will collapse when no basic good is at stake. But can we argue just as effectively, using Finnis's theory, that we do not have a moral duty to obey the 1798 Sedition Act? How could Finnis argue that we have a moral duty not to obey the 1798 Sedition Act?

The elements that go into the duty to obey analysis and its defeasibility are more than just the cost of civil insurrection. The generic and presumptive duty to obey may be defeasible as long as we disobey the law under certain conditions. One of these conditions is that the act of disobedience must be done for "symbolic purposes". In Lyons's case there is no evidence that the printing was made for anything but symbolic purposes.

The act must not be done to inspire a corrupting example. There is no doubt that, in Lyons's case, it is not unreasonable to assume that many corrupting examples were made by the publication, but there is no empirical evidence of this fact. Lyons's publication was made at the time of the founding of a new society, and the potential for political chaos in these situations is quite high. Rebels are found more frequently when the conditions for rebellion are ripe or have just recently passed, but as history revealed, the society functioned fine after Lyons'publication. No one ever presented evidence that Lyons's material created any sort of destructive political consequences.

Finnis claims that further condition for defeasibility is that an act cannot be committed that would bring chaos or destruction to a society. ${ }^{24}$ It is not clear by this test whether the society would have melted down after Lyons's publication. Lyons's attacks on the President were not, after all, calling on people to overthrow their government. In other words, it is hard to believe, based on the nature of Lyons's attacks on the President, that the society would melt down. Lyons's attacks were more innocuous than anything else. In fact, the prosecution, one might argue, was politically motivated to shut down Lyons, and as such, they were just looking for some bogus way of sending Lyons to jail to silence him so the President's cronies, including the prosecutor, could keep their jobs and salaries at the expense of the taxpayers.

FINNIS, J. Aquinas: Moral, Political and Legal Theory. Oxford: Oxford University Press, 1998, p. 275.

FINNIS, J. Natural Law and Natural Rights. Second Edition. Oxford: Oxford University Press, 2011, p. 462. 


\section{CONCLUSION}

Good arguments can be made both that we do and that we do not have a duty to obey the 1798 Act. One explanation of this two-sidedness is that the analysis leaves us with a problem in deciding which of the factors we should apply in a given case. Finnis does not give us any direction on the number or the weight of the factors to be used in specific situations. This vagueness has a tendency to create subjective results when we are trying to obey an extrinsically unjust law.

In the case of the 1798 Sedition Act, all of the defeasibility elements, with perhaps the exception of the corrupting example, may be enough for us to say that what Lyons did was enough to allow him to divest his moral duty to obey the unjust law. The point here is that Finnis needs to be clearer on the application of the defeasibility elements and the common good analysis. His theory hardly assists someone who is faced with trying to decide whether to obey or disobey an archaic and exploitative law that suppresses much political free speech. The lack of a convincing result on either side means that the presumptive duty to obey will win out and thus for the majority of extrinsically unjust laws we will have a duty to obey them.

The issue may be summed up as the free political speech problem for Finnis, that is, that our right to free political speech may be suppressed too severely by Finnis's doctrine of the generic and presumptive duty to obey the law. To prevent against this tendency in his theory, free speech should be made a basic good.

\section{KEY WORDS}

Natural law, common good, extrinsically unjust law, free speech

\section{KLÍČOVÁ SLOVA}

Přirozené právo, obecné dobro, externě nespravedlivý zákon, svoboda projevu

\section{BIBLIOGRAPHY}

1. CROWE, J. Natural Law and the Nature of Law. Cambridge: Cambridge University Press, 2019. DOI:https://doi.org/10.1017/9781108653237

2. EMERSON, T. The System of Freedom of Expression. Random House, 1970.

3. EMERSON, T. The Doctrine of Prior Restraint. Law and Contemporary Problems, Vol. 20, Issue 4, 1955. Dostupné na: https://doi.org/10.2307/1190292.

4. FINNIS, J. Natural Law and Natural Rights, Second Edition. Oxford: Oxford University Press, 2011.

5. FINNIS, J. Law's Authority and Social Theory's Predicament. in: Philosophy of Law: Collected Essays, Volume IV, Oxford University Press, 2011.

6. FINNIS, J. Natural Law and the Ethics of Discourse. American Journal of Jurisprudence, Vol. 43, Issue 1, 1998. Dostupné na: https://doi.org/10.1093/ajj/43.1.53.

7. FINNIS, J. What is the Common Good, and Why Does It Concern the Client's Lawyer? South Texas Law Review, Vol. 41, 1999.

8. FINNIS, J. Aquinas: Moral, Political and Legal Theory. Oxford: Oxford University Press, 1998.

9. GEAROM, L. Freedom of Expression and Human Rights. Sussex Academic Press, 2006.

10. GRISEZ, G., BOYLE, J., FINNIS, J. Nuclear Deterrence, Morality, and Realism. Oxford: Clarendon Press, 1987.

11. MARLIN, R. Propaganda and The Ethics of Persuasion. Broadview Press, 2013.

12. MILL, J. S. On Liberty. Batoche Books, 2001.

13. RACHLIN, R. D. The Sedition Act of 1798 and the East-West Political Divide in Vermont. The Journal of the Vermont Historical Society, Vol. 78, No. 2, 2010. 


\section{CONTACT DETAILS OF THE AUTHOR}

JUDr. Petr Osina, Ph.D.

Senior Lecturer

Palacky University Olomouc, Faculty of Law

Department of Legal Theory and Legal History

tr. 17. listopadu 8, Olomouc 771 11, Czech Republic

Phone number: +420 585637611

Email: petr.osina@upol.cz 